\title{
CrimRxiv
}

\section{The Coupling of Safety and Security: Exploring Interrelations in Theory and Practice}

Corinne Bieder, Kenneth Pettersen Gould

Published on: Mar 04, 2022

DOI: $10.21428 / \mathrm{cb} 6 \mathrm{ab} 371.55 \mathrm{e} 59340$

License: Creative Commons Attribution 4.0 International License (CC-BY 4.0). 
